\title{
OD WROGA KLASOWEGO DO WROGA ETNICZNEGO - EWOLUCJA KOMUNISTYCZNEJ MYŚLI POLITYCZNEJ NA PRZYKŁADZIE POLSKIEJ PARTII ROBOTNICZEJ I POLSKIEJ ZJEDNOCZONEJ PARTII ROBOTNICZEJ W LATACH 1942-1968
}

\begin{abstract}
Podmiotem rozważań były Polska Partia Robotnicza i Polska Zjednoczona Partia Robotnicza, partie komunistyczne o ideologii marksistowsko-leninowskiej, które zbudowały system polityczny Polski Ludowej i sprawowały władzę polityczną. Autorka zajęła się myślą polityczną, a szczególnie jedną z jej kategorii - wróg. Celem artykułu było pokazanie ewolucji myśli politycznej partii komunistycznych przy wykorzystaniu przedmiotowej kategorii i z uwzględnieniem wroga rzeczywistego oraz tzw. obiektywnego i potencjalnego. System polityczny stworzony przez komunistów potrzebował wroga. Lokalizacja wroga była pochodną narzuconych przez suwerena zewnętrznego wskazań ideologicznych, politycznych i wojskowych. Wrogiem klasowym, zarówno rzeczywistym, jak też obiektywnym i potencjalnym, były różne podmioty: siły społeczne, polityczne i wojskowe związane z poprzednim państwem, a w okresie wojny z Polskim Państwem Podziemnym państwa kapitalistyczne, po utrwaleniu władzy zaś - kolejne grupy społeczne, instytucje, środowiska zawodowe, członkowie elity władzy. Wrogiem potencjalnym były mniejszości narodowe i ich stowarzyszenia, które, w zależności od potrzeb mogły przeobrazić się we wroga obiektywnego i rzeczywistego. PPR i PZPR, wzorem innych partii komunistycznych, stosowała elastyczne formy i środki walki z wrogiem, w zależności od potrzeb: przemoc fizyczną, dyskredytację, infiltrację, dyskryminację materialną, charakterystyczne dla okresu walki o władzę i jej utrwalenie, i inne, np. wymuszanie emigracji, czy szykany w postaci odmowy wydania paszportu, aresztu 48-godzinnego, rewizji, zablokowania możliwości awansu, blokady dostępu na studia.

Słowa kluczowe: myśl polityczna, wróg klasowy, wróg etniczny, wróg realny, wróg obiektywny, wróg potencjalny.
\end{abstract}

\section{UWAGI WSTĘPNE}

Wróg, jedna z kategorii myśli politycznej, był immanentną cechą komunistycznego stylu myślenia, odzwierciedloną w ideologii marksistowsko-leninowskiej, a następnie w systemie politycznym stworzonym przez komunistów. System totalitarny, oprócz realnie istniejących wrogów $\mathrm{w}$ postaci podmiotów kwestionujących i walczących $\mathrm{z}$ komunistycznym porządkiem, wytworzył kategorie wrogów - obiektywnego i potencjalnego.

Kategoria wroga obiektywnego odnosiła się do jakiegoś podmiotu nie ze względu na jego uczynki bądź zaniechania, lecz wskutek arbitralnego wskazania i naznaczenia przez

\footnotetext{
${ }^{1}$ Prof. dr hab. Krystyna Trembicka, Wydział Politologii, UMCS Lublin, Plac Litewski 3, 20-080 Lublin, tel. 08153760 00, e-mail: krystynatrembicka@wp.pl
} 
rządzących ${ }^{2}$. Winą subiektywną były konkretne działania przeciwko partii. Teorię „,wroga obiektywnego" pierwsza sformułowała Hannah Arendt, wskazując, że w stworzonym wzorcu został on wyposażony w niezmienne i niezbywalne cechy. Wrogiem obiektywnym mógł być każdy, kto „stoi na drodze procesu [...] historycznego, który wydał wyrok na [...] «gnijące klasy»”. Zmiana rzeczywistości zgodnie ze wskazaniami własnej ideologii musiała niejako w naturalny sposób prowadzić do „rozmnożenia” wroga $^{3}$.

Wróg potencjalny był pochodną potencjalnego przestępstwa, czyli takiego, które rządzący mogli sobie wyobrazić, abstrahując od tego, czy zostało realnie popełnione. Potencjalnym wrogiem, a co za tym idzie - prawdopodobną ofiarą był każdy, kto miał „,złe” pochodzenie społeczne, kontakt z zagranicą, na przykład miał tam rodzinę. Istniało prawdopodobieństwo, że osoby te, podobnie jak „filateliści czy esperantyści, zostaną oskarżone o szpiegostwo"4 . Potraktowanie jako wrogów tych wszystkich, którzy mieli choćby niewielki kontakt z ,innym światem”, miało na celu zlikwidowanie potencjalnej mitycznej ,piątej kolumny”.

Stwierdzić należy, że w państwie komunistycznym ofiarą antykapitalistycznej rewolucji stały się różne grupy uznane za „klasowo obce” i „nowemu społeczeństwu” nieprzydatne: ziemianie, „burżuazyjni specjaliści” i osoby wykonujące wolne zawody, drobni prywatni przedsiębiorcy, rzemieślnicy, kupcy, chłopi, a spośród mieszkańców miast - wszyscy, którzy nie mieścili się w formule proletariatu.

\section{WRÓG KLASOWY W POLSCE LUDOWEJ}

W chwili odtworzenia na ziemiach polskich partii komunistycznej w postaci Polskiej Partii Robotniczej (PPR) głównym i rzeczywistym wrogiem była z jednej strony III Rzesza Niemiecka, a z drugiej rząd polski w Londynie, struktury Polskiego Państwa Podziemnego. Stosunek komunistów do polskich władz był pochodną relacji polskoradzieckich. Zmiana odniesienia do rządu i odmowa prawa do występowania w imieniu narodu polskiego nastąpiła po zerwaniu przez rząd radziecki umowy z Polską w związku z odkryciem przez Niemców grobów oficerów pomordowanych przez NKWD w Katyniu i skierowaniem tam przy polskiej aprobacie delegacji międzynarodowej.

Kategoria wroga klasowego podlegała ewolucji: najpierw byli to „agenci hitleryzmu” $i$ „rozbijacze” frontu narodowego, a następnie określano go jako „reakcja”, „Rozbijaczami frontu narodowego" musieli stać się w zasadzie wszyscy, którzy nie chcieli współpracy z komunistami. Z kolei termin „reakcja” był wyjątkowo pojemny, bo w zależności od potrzeb mieścił w sobie różne podmioty: państwa, grupy społeczne, środowiska, organizacje i instytucje polityczne. „Faszyści”, „,agenci hitleryzmu”, „zdrajcy i kolaboranci" - inwektywy kierowane pod adresem przeciwników politycznych z obozu londyńskiego i ich krajowych struktur objęły wszystkich, którzy nie podzielali

\footnotetext{
${ }^{2}$ Zob. R. Bäcker, Totalitaryzm. Geneza. Istota. Upadek, Toruń 1992, s. 48; A. Walicki, Marksizm i skok do królestwa wolności: Dzieje komunistycznej utopii, Warszawa 1996, s. 292-293.

${ }^{3}$ H. Arendt, Korzenie totalitaryzmu, t. 2, tłum. D. Grinberg, M. Szawiel, Warszawa 2008, s. 19, 235.

${ }^{4}$ N. Werth, Państwo przeciw społeczeństwu. Przemoc, represje i terror w Zwiazku Sowieckim, [w:] S. Cortois, N. Werth i in., Czarna księga komunizmu. Zbrodnie, terror, prześladowania, wstęp do polskiego wydania K. Kersten, Warszawa 1999, s. 183-184.

${ }^{5}$ Publicystyka konspiracyjna PPR 1942-1945, t. 2, Warszawa 1964, s. 267.
} 
komunistycznego sposobu myślenia. Terminy „faszyzm” i ,antyfaszyzm” były ważną konstrukcją ideologiczną stworzoną na użytek walki o władzę. Dostarczyły wygodnej figury retorycznej do walki z wrogiem, ulokowanym wewnątrz państwa oraz poza jego granicami. Pretekst walki z faszyzmem był ważnym atutem, pozwolił bowiem likwidować zarówno jednostki, jak i ważne podmioty polityki: organizacje polityczne, zbrojne, instytucje, grupy społeczne, zawodowe i narodowe.

Antyfaszyzm był swoistym mitem założycielskim Polski Ludowej, szczególną wizją przeszłości, pokazującą, że tylko komuniści realnie walczyli z III Rzeszą Niemiecką. Traktowanie sanacji jako polskiej odmiany faszyzmu, ustroju II RP jako faszystowskiego, powielanie w podręcznikach do historii nieprawdziwej i krzywdzącej tezy o bezczynności Armii Krajowej - to wszystko było jednym z ważnych elementów delegitymizacyjnych wszystko, co było związane z poprzednim państwem.

Koniec wojny przyniósł kolejne zagrożenia. Zamiast wroga, jakim była III Rzesza Niemiecka, pojawił się nowy w postaci „,świata kapitalistycznego”: imperializmu Stanów Zjednoczonych, Wielkiej Brytanii, a po 1949 r. Republiki Federalnej Niemiec. Dla komunistów ,świat kapitalistyczny” był realnym wrogiem, co nie oznaczało podjęcia z nim czynnej walki. Ulokowanie zagrożenia w demokracjach zachodnich było stałą tendencją i obowiązywało przez cały okres Polski Ludowej. Wewnątrz państwa zagrożeniem dla władzy ludowej i planu odbudowy kraju były „reakcja”, a następnie Polskie Stronnictwo Ludowe (PSL). Czasowy kompromis z częścią sił politycznych tworzących rząd londyński, wymuszony decyzjami Wielkiej Trójki w Jałcie, nie zmienił stosunku komunistów do sił politycznych reprezentowanych w rządzie. Warunkowy udział w utworzonym 28 czerwca 1945 r. Tymczasowym Rządzie Jedności Narodowej kilku osób reprezentujących inny niż „demokratyczny” obóz polityczny wykluczył zamiar podzielenia się władzą. Polskie Stronnictwo Ludowe Stanisława Mikołajczyka stało się szybko naturalnym i rzeczywistym wrogiem, gdyż było niezależne i miało alternatywną wizję Polski.

W okresie walki o umocnienie władzy podstawowym i realnym wrogiem było podziemie zbrojne, traktowane jako ekspozytura „obcych”, proniemieckich sił reakcyjnych, PSL, a spośród grup społecznych tak określano ziemian, ich zaplecze polityczne i materialne. Podziemie nieustannie przeszkadzało w odbudowie kraju, usiłowało „mącić życie polityczne kraju, hamować pracę, opóźniać odbudowę”6. Podkreślano rozkład i ,zgniliznę” tego obozu. W 1947 r. pojawili się „oni”, czyli wszyscy ci, którzy chcieli zablokować przekształcenia prosocjalistyczne w gospodarce ${ }^{7}$. Można uznać, że wśród pojemnej kategorii „oni” znaleźli się zarówno wrogowie realni, jak i liczni wrogowie obiektywni i potencjalni ulokowani w różnych środowiskach społecznych, organizacjach i instytucjach, których w zależności od potrzeb można było ujawnić.

„Zwycięstwo” wyborcze PPR w 1947 r. przesądziło o losie partii politycznych. Część ugrupowań politycznych nie uzyskała zgody na legalną działalność bądź nie zdążyła jej

\footnotetext{
${ }^{6}$ Uchwała plenum KC PPR „O najważniejszych momentach sytuacji politycznej Polski” [18 września 1946 r.], [w:] PPR. Rezolucje, odezwy, instrukcje i okólniki Komitetu Centralnego I 1946I 1947, oprac. W. Góra, B. Halaba, N. Kołomejczyk, Warszawa 1961, s. 145.

${ }^{7}$ O aktualnej sytuacji gospodarczej $i$ zadaniach partii [referat Biura Politycznego na plenum KC PPR z 14 kwietnia 1947 r.], [w:] Polska Partia Robotnicza. Dokumenty programowe 1942-1948, wyboru i oprac. dokumentów dokonał zespół M. Malinowski i in., Warszawa 1984, s. 379.
} 
rozwinąć. Do jesieni 1947 r. legalna opozycja została rozbita, osłabiona została także antykomunistyczna konspiracja. Redefinicji uległa kategoria wroga. O ile wcześniej wrogiem była reakcja $\mathrm{w}$ rozumieniu zorganizowanych sił politycznych, związanych najpierw z rządem londyńskim, następnie z PSL, o tyle po 1947 r. stały się nim różne grupy społeczne. Totalitaryzm skutkował atakiem na wszystkie grupy społeczne $\mathrm{z}$ założeniem rozbicia istniejących dotąd więzi społecznych, co było możliwe dzięki wykreowaniu tzw. wroga obiektywnego i potencjalnego.

Charakterystyczna dla lat 1949-1956 i rozstrzygająca, narzucona przez suwerena zewnętrznego nowa ocena rzeczywistości politycznej w postaci tezy o zaostrzeniu walki klasowej, w miarę przybliżania się do socjalizmu, skutkowała także wyznaczeniem nowych zadań i zlokalizowaniem kolejnych wrogów. Potraktowanie państw demokracji ludowej jako państw dyktatury proletariatu z zadaniem budowy socjalizmu na podstawie wzorca radzieckiego oznaczało przyspieszenie przekształceń gospodarczych i społecznych. Realizacja projektu kolektywizacji rolnictwa, likwidacja prywatnego przemysłu i handlu jako jedynych słusznych rozwiązań ustrojowych, przebudowa społeczeństwa i tworzenie nowego człowieka musiały godzić w duże grupy społeczne. Do wcześniej zlokalizowanych wrogów, mieszczących się w pojemnej grupie o łącznej nazwie - reakcja, uwzględniającej różne grupy społeczne, ulokowane wysoko w strukturze społecznej II RP, czyli ziemian, przedsiębiorców, urzędników, w części inteligencji, duchownych, żołnierzy różnych niekomunistycznych formacji zbrojnych i członków ich rodzin, dodano nowych. Nowym wrogiem stali się chłopi gospodarze (według przeszczepionego na grunt Polski bolszewickiego nazewnictwa „kułacy”), oraz kupcy.

Obiektywnym wrogiem stali się także wyeliminowani z kierownictw partyjnych przywódcy PPR i Polskiej Zjednoczonej Partii Robotniczej (PZPR). Było to konsekwencją tzw. odchylenia prawicowo-nacjonalistycznego, pierwszej w PZPR herezji, odstępstwa od ideologii w wersji narzuconej przez suwerena zewnętrznego, ponieważ socjaliści i ludowcy nie zaakceptowali zjednoczenia PPS i PPR i, jak przypuszczano, chcieli rozbić ruch robotniczy za pomocą ,zamaskowanych agentur i dywersji ideologicznej"8. W 1949 r. wrogiem okazał się Kościół katolicki, który stał się „organizatorem i wyrazicielem całej polityki obozu reakcyjnego w Polsce”. Zgodnie z praktyką radziecką wrogiem mógł być każdy, kto za takiego został uznany przez władze.

Sposób ujawniania wroga obiektywnego i potencjalnego dobrze obrazowało III Plenum KC PZPR w 1949 r. Polska Zjednoczona Partia Robotnicza w nowej rzeczywistości za wroga klasowego uznała różne grupy społeczne i zawodowe. Przemawiający komuniści, diagnozując rzeczywistość, rozszerzyli obszary penetracji wroga na środowiska, w których sami funkcjonowali i zapewniali, że wróg był groźny, bo stosował sabotaż gospodarczy, jego metody były wyrafinowane, należało zatem szczegółowo analizować przyczyny każdej awarii, aby zniwelować „wrogą robotę”, zdemaskować szkodników i sabotażystów. Wrogowie znajdowali się w redakcjach, w wydawnictwach, prowadzili niebezpieczną dla państwa ludowego propagandę. Wrogowie

\footnotetext{
${ }^{8}$ B. Bierut, Sprawozdanie KC PZPR. Referat wygłoszony 10 marca 1954 r. w czasie II Zjazdu PZPR, [w:] II Zjazd PZPR, Warszawa 1954, s. 3 i n.

9 Odprawa z dnia 28 lipca 1949 r., [w:] Aparat bezpieczeństwa w latach 1944-1956: taktyka, strategia, metody, cz. 2: Lata 1948-1949, oprac. A. Paczkowski, Warszawa 1994, s. 169 (podsumowanie Romana Romkowskiego, wiceministra Ministerstwa Bezpieczeństwa Publicznego).
} 
znajdowali się w środowisku socjalistów, w „transmisjach masowych” (związkach zawodowych), aparacie bezpieczeństwa, aparacie państwowym i partyjnym ${ }^{10}$.

III Plenum KC PZPR pozwoliło na ukazanie ewolucji metafory wroga, jaka nastąpiła w dobie stalinowskiej. Rafał Stobiecki, znawca bolszewickiej filozofii dziejów, zauważył, że o ile w okresie leninowskim ,wróg był przede wszystkim rywalem w walce o władzę”, a jego działalność „,dotyczyła głównie sfery politycznej”, o tyle później „,metafora wroga rozprzestrzenia się na wszystkie dziedziny życia - politykę, gospodarkę, kulturę, szeroko rozumianą codzienność obywateli"11. Zmiana wyobrażeń o realnych bądź tylko potencjalnych zagrożeniach powodowała, że wrogiem klasowym mógł zostać każdy, bez względu na status czy wykonywany zawód. Pewne za to było, że wróg działał niejawnie i $\mathrm{z}$ tego powodu był szczególnie niebezpieczny.

Charakterystyczna dla komunistycznego stylu myślenia skłonność do kreowania wrogów wśród partii politycznych, instytucji, grup społecznych, państw, autorytetów, we własnym otoczeniu skutkowała wieloma wojnami. Z punktu widzenia funkcjonariuszy partyjnych niepożądane i groźne były różne osoby prezentujące niewłaściwy sposób myślenia i działania. Adam Humer, szczególnie okrutny funkcjonariusz Ministerstwa Bezpieczeństwa Publicznego, zaznaczył, że nie chodziło o to, aby „nie bić aresztowanego”, ale o „bezradność i bezczynność wobec licznych bezkarnie uchodzących nieprawości" ${ }^{12}$. Zagrożenie nieśli nawet ferujący wyroki sędziowie i oskarżający wrogów prokuratorzy, niebezpieczne były ich „niedostateczny hart i dojrzałość”. Liberalna postawa sędziów prowadziła do wadliwego wykonywania obowiązków, czego przykładem był chociażby brak interwencji wobec nagannych postaw osób rehabilitowanych, którzy chcieli rehabilitować nie tylko siebie, ale i swoje poglądy polityczne. W tym ostatnim wypadku chodziło o zwalnianych $\mathrm{z}$ więzień, na mocy amnestii z kwietnia 1956 r., osadzonych w poprzednim okresie. Rządzący nie mieli zamiaru przyznać, że represjonowani byli niewinni.

W 1956 r. wróg znalazł się w środowisku strajkujących robotników. Potwierdzał to stosunek komunistów do strajków. Protesty w Poznaniu, mimo infiltracji środowisk robotniczych, zaskoczyły rządzących. W bezpośrednim niejako „odruchu” został przez rządzących uznany za prowokację, za świadome działanie wroga, który wykorzystał niezadowolenie robotników w celu osłabienia socjalistycznego państwa. Zgodnie z przyjętą wykładnią strajki i demonstracje poznanian zinterpretowano jako efekt kontrrewolucji, dzieło agentów imperialistycznych i prowokatorów. Józef Cyrankiewicz, ówczesny premier, 29 czerwca 1956 r. w przemówieniu radiowym na temat wydarzeń i przewidywanych działań przeciwko demonstrantom zagroził nawet „odrąbaniem ręki”,

\footnotetext{
10 Wystąpienie Stefana Staszewskiego, Józefa Cyrankiewicza, Henryka Jabłońskiego, Sylwestra Zawadzkiego, Stanisława Radkiewicza, Oskara Langego, Michała Strzeleckiego w dyskusji nad referatem B. Bieruta Zadania Partii w walce o czujność rewolucyjna na tle sytuacji obecnej, [w:] III Plenum Komitetu Centralnego Polskiej Zjednoczonej Partii Robotniczej (11, 12, 13 listopada 1949 r.), ,Nowe Drogi” 1949 [numer specjalny], s. 74, 89, 96, 123, 159, 165-166, 169, 188.

${ }^{11}$ R. Stobiecki, Bolszewizm a historia. Próba rekonstrukcji bolszewickiej filozofii dziejów, Łódź 1998, s. 155.

12 Stenogram dyskusji na naradzie krajowej aktywu kierowniczego aparatu bezpieczeństwa publicznego 4 marca 1954 r., [w:] Aparat bezpieczeństwa w Polsce w latach 1953-1954. Taktyka, strategia, metody, wstęp A. Paczkowski, wybór i oprac. G. Majchrzak, A. Paczkowski, Warszawa 2004 , s. 317.
} 
podniesionej na władzę ludową ${ }^{13}$. Strajki i demonstracje uznano za działalność dywersyjną. Dopiero po przesileniu w elicie władzy Gomułka, nowy I sekretarz KC PZPR, przyjął strajki w Poznaniu jako zasadne i usprawiedliwione ${ }^{14}$.

Ocena strajków jako słusznych, bo wynikających z wieloletnich zaniedbań i błędów po stronie rządzących, przekonanie o autonomii robotników przy podejmowaniu tego typu działań na niewiele się zdały. Sprawdzian intencji władz nastąpił już w następnym roku, w czasie kolejnej fali strajków. Mimo werbalnego docenienia robotników, stosunek do strajków w dobie Gomułki był de facto podobny jak w poprzednim okresie. Wybuchające w różnych okresach strajki, głównie z powodów ekonomicznych, miały organizować „elementy wrogie i warcholskie”, wobec których należało zastosować odpowiednie sankcje. Zadaniem lokalnej organizacji partyjnej miało być ustalenie personaliów organizatorów strajku i spowodowanie zwolnienia ich $\mathrm{z}$ pracy bez odszkodowania ${ }^{15}$. Trzeba stwierdzić, że „wrogie i chuligańskie elementy” stały się motywem przewodnim i siłą sprawczą większości „,przerw w pracy” w PRL.

Przełom 1956 r. nie zlikwidował zagrożeń, przeciwnie - pojawiły się nowe. Komuniści obwieścili kolejne niebezpieczeństwo. Oto pod pozorem walki o demokrację ujawniły się siły zainteresowane ,demokracją kapitalistyczną”. W propagandzie ożyły „elementy reakcyjne”, które wysuwając hasła antyradzieckie, godziły w sojusz polskoradziecki. Z odezwy wydanej 2 listopada 1956 r. wynikało, że w sytuacji kiedy „tu i ówdzie zdarzają się nierozsądne, nieodpowiedzialne wystąpienia klasy robotniczej, wszyscy świadomi obywatele winni im dać zdecydowany opór"16. Oprócz reakcji wrogiem były „elementy obce”. Podział, a co za tym idzie - front walki był podobny jak wcześniej, miał bowiem przebiegać między z jednej strony „siłami socjalizmu”, zogniskowanymi wokół partii, a z drugiej „siłami reakcji”, które miały podejmować działania wymierzone w partię. Charakterystyczne było skoncentrowanie uwagi na wrogu ulokowanym w partii rządzącej, którym stali się tzw. rewizjoniści. Uchwała VIII Plenum KC PZPR z 1956 r. zapowiedziała najpierw konsolidację, a następnie wojnę: przejście do kontrnatarcia przeciwko „obcym naroślom” oraz „wrogiej ideologii”17.

Rewizjonistami nazwano część elity władzy, która swoją aktywność zintensyfikowała w związku z wydarzeniami 1956 r. i rozbudzonymi wówczas nadziejami na zmiany we wszystkich dziedzinach. Jak pisał Andrzej Friszke, historyk i badacz tej problematyki, popaździernikowi „buntownicy” wyciągnęli wnioski z krytyki stalinizmu i domagali się głębokiej przebudowy ustroju, aby zbliżyć się do ,pierwotnego socjalizmu”, odwoływali się do marksizmu ${ }^{18}$.

Analiza wypowiedzi I sekretarza KC PZPR pozwala zauważyć, że Gomułka już w pierwszym roku sprawowania władzy miał zastrzeżenia do wielu grup społecznych.

\footnotetext{
${ }^{13}$ A. Garlicki, Z tajnych archiwów, Warszawa 1993, s. 226.

${ }^{14}$ W. Gomułka, Przemówienie w czasie VIII Plenum KC PZPR, „Nowe Drogi” [dalej ND] 1956, nr 10, s. 27.

${ }^{15}$ Zob. Protokót z posiedzenia Biura Politycznego w dniu 14 sierpnia 1957 roku, [w:] Dokumenty do dziejów PRL. Centrum władzy. Protokoty posiedzeń kierownictwa PZPR. Wybór z lat 19491970, oprac. A. Dudek, A. Kochański, K. Persak, Warszawa 2000, s. 272-273.

16 „Trybuna Ludu” 2 XI 1956.

${ }_{17} O$ aktualnych zadaniach politycznych i gospodarczych partii. Uchwała VIII Plenum KC PZPR, [w:] VIII Plenum Komitetu Centralnego PZPR 19-21 X 1956 r., ND 1956/10, s. 5-6, 8-9.

${ }^{18}$ A. Friszke, Opozycja polityczna w PRL 1945-1980, Londyn 1994, s. 133 i n.
} 
Piętnował „elementy” antysowieckie, aktywnych nacjonalistów, jawnych klerykałów, uczestników masowych akcji organizowanych przez „kler”, głosicieli antysocjalistycznych poglądów ${ }^{19}$. Specyficzny kod językowy krył pod tymi nazwami różne grupy wskazujące na brak suwerenności państwa i zależność od Związku Radzieckiego, między innymi katolików uczestniczących w pielgrzymkach i nabożeństwach, a także domagające się podstawowych wolności oraz demokratyzacji kraju, do których należeli także członkowie partii komunistycznej. Dla Gomułki byli to obiektywni wrogowie partii komunistycznej. Domniemane zagrożenie dla socjalizmu w dobie odwilży było dobrym alibi, uzasadniającym potrzebę utrzymania dotychczas obowiązującego sposobu sprawowania władzy.

Ogląd rzeczywistości w odniesieniu do świata zewnętrznego doby Gomułki, ale i Gierka i Jaruzelskiego nie różnił się zbytnio od reprezentowanego przez rządzących w poprzednim okresie. Świat był nadal spolaryzowany, konstatowano jedynie zmianę metod walki świata kapitalistycznego z socjalistycznym. Konfrontację wojskową między dwoma blokami zastapiło starcie ideologiczne. Nieustannie podejmowana przez państwa zachodnie ofensywa miała służyć rozbiciu jedności i spoistości bloku, podważeniu sojuszu polsko-radzieckiego. Skutkiem polityki „rozmiękczania” były wzrost sił antysocjalistycznych w Czechosłowacji i kontrrewolucja. Przyjęta konstatacja pozwoliła na dokończenie wojny z rewizjonistami oraz podjęcie nowej - tym razem z syjonistami i kosmopolitami. W tym ostatnim wypadku chodziło o wszystko, co miało związek z obecnymi w Europie Zachodniej modami i ideami.

Należy stwierdzić, że dokonywane oceny rzeczywistości były wyjątkowo stabilne. W niemal ćwierć wieku od przejęcia przez komunistów władzy Gomułka w wystąpieniach adresowanych do członków elity władzy, bo tak należy traktować uczestników spotkań plenarnych KC PZPR i zjazdu, konstatował zaostrzenie walki klasowej w Polsce, istnienie „sił prawicy społecznej”. Choć doszło do likwidacji klas o przeciwstawnych interesach, to nie wyeliminowano walki klasowej i zagrożenia dla socjalizmu. Potrzeba rozprawy z rewizjonistami i obrony dotychczasowego porządku stanowiła przesłankę dla przypomnienia, że wewnętrzną funkcją dyktatury proletariatu była ochrona ustroju przed wrogiem wewnętrznym i zewnętrznym ${ }^{20}$.

\section{WROGOWIE ETNICZNI}

Na początku kształtowania się Polski Ludowej spośród grup narodowych wrogiem byli Niemcy i Ukraińcy. Niemcy, którzy przybyli na ziemie polskie wraz z armią i pełniący w czasie wojny różne funkcje jako część aparatu okupacyjnego, musieli opuścić kraj. Niemcy osiedleni wcześniej, a zaliczani do mniejszości narodowej, po wyzwoleniu pełnili funkcję kozła ofiarnego, mimo że mieli szansę na adaptację do warunków socjalistycznego państwa. Niemniej konsekwencją realizacji stalinowskiego modelu

19 Zob. Protokót z posiedzenia Biura Politycznego w dniu 1 października 1957 roku, [w:] Dokumenty do dziejów PRL. Centrum wtadzy..., s. 275-276.

${ }^{20}$ Sprawozdanie KC oraz zadania partii $w$ dziedzinie umacniania socjalizmu $i$ dalszego rozwoju PRL [referat I sekretarza KC PZPR tow. Władysława Gomułki], ND 1968/12, s. 38; V Zjazd Polskiej Zjednoczonej Partii Robotniczej. Stenogram, Warszawa 1969, s. 135. 
polityki narodowościowej ostatecznie było uznanie wszystkich Niemców za wrogów narodu polskiego ${ }^{21}$.

Po zakończeniu wojny dla Polski realnym i podstawowym zadaniem było usunięcie irredenty i z tego względu komunistyczne władze akceptowały postanowienia konferencji w Poczdamie o wysiedleniu ludności niemieckiej z Ziem Odzyskanych. Poza tym idea stworzenia de facto państwa jednonarodowego musiała skutkować różnego rodzaju represjami w stosunku do mniejszości narodowych. Aprobowano stalinowską koncepcję przemieszczenia ludności, co skutkowało usunięciem ludności ukraińskiej z ziem południowo-wschodniej Polski i osadzeniem jej na Ziemiach Odzyskanych. Dopiero po 1956 r. mniejszości narodowe uzyskały pewne prawa w zakresie oświaty i kultury. Rządzący zakreślili jednocześnie granice egzekwowania tego prawa. Powstałe stowarzyszenia, jak wiele innych, musiały zajmować się ,transmisją” programu partii do swoich członków, miały zablokowaną możliwość aktywności politycznej i stale podlegały kurateli Ministerstwa Spraw Wewnętrznych ${ }^{22}$.

Należy stwierdzić, że dla komunistów potencjalnym wrogiem - i to do końca istnienia PRL - były niektóre grupy etniczne i ich reprezentacje. Tak traktowano Kaszubów i Zrzeszenie Kaszubskie, a następnie Zrzeszenie Kaszubsko-Pomorskie. Kaszubów, których w czasie II wojny światowej Niemcy wpisali na niemiecką listę narodowościową, oskarżano o filogermanizm, separatyzm i niechęć do ustroju komunistycznego. Pretekstem była duża aktywność stowarzyszenia, które po Październiku domagało się znacznie większego zakresu praw niż komuniści byli w stanie zaakceptować: dostępu Kaszubów do urzędów, kultywowania kultury i odrębności językowej. Z tego też względu organizacja podlegała stałej inwigilacji ${ }^{23}$.

W rzeczywistości Polski Ludowej nową jakość przyniósł rok 1968. W 1968 r. pojawił się wróg etniczny w postaci tzw. syjonistów. Syjonizm, traktowany jako wroga ideologia, wcześniej nie był oceniany jako groźny ze względu „na małą atrakcyjność” oraz brak dostatecznie dużego zaplecza społecznego. Niemniej w konkretnej sytuacji został potraktowany jako część kampanii przeciwko Polsce, organizowanej przez ośrodki zewnętrzne. Syjonizm stał się wrogą Polsce ideologią, gdyż zdaniem rządzących zawierał w sobie negatywny obraz Polaków ${ }^{24}$. W okresie kolejnej wojny między państwami arabskimi a Izraelem sympatie Polaków dla Izraela dały rządzącym w Polsce komunistom pretekst do sformułowania zarzutów przeciwko niedookreślonym do końca syjonistom. Chodziło o osoby, które miały jakoby charakteryzować się postawą uległości wobec „kosmopolitycznego nihilizmu narodowego” i „ciasnego nacjonalizmu”. Pożądane zaś były patriotyzm i ,moralność socjalistyczna" ${ }^{25}$. Kosmopolityzm był aluzja do pochodzenia żydowskiego, zarzutem wobec postawy jakoby wyszydzającej polskie

\footnotetext{
${ }^{21} \mathrm{O}$ istocie stalinowskiej polityki narodowościowej zob. E. Mironowicz, Polityka narodowościowa PRL, Białystok 2000, s. 93-94.

${ }^{22}$ L. Olejnik, Polityka narodowościowa Polski w latach 1944-1960, Łódź 2003, s. 600.

${ }^{23}$ A. Paczoska, Oskarżeni o separatyzm. Działania tajnych stużb PRL wobec działaczy Kaszubskich w latach 1945-1970, „Pamięć i Sprawiedliwość. Biuletyn Głównej Komisji Badania Zbrodni przeciwko Narodowi Polskiemu" 2004/2, s. 210, 216-217, 230.

${ }^{24}$ Przemówienie W. Gomutki w czasie XII Plenum KC PZPR [8-9 lipca 1968 r.], ND 1968, nr 8, s. 133.

${ }^{25}$ Sprawozdanie $K C$ oraz Zadania partii $w$ dziedzinie umacniania socjalizmu $i$ dalszego rozwoju PRL. Referat I sekretarza KC PZPR tow. Wtadystawa Gomutki, ND 1968/12, s. 39.
} 
tradycje patriotyczne i nadmierną usłużność wobec władz Związku Radzieckiego. O ile o pierwszych można było mówić głośno, o tyle o tych drugich nieoficjalnie, niejako ,na ucho". Trzeba podkreślić, że walka z syjonizmem była częścią szerszego procesu i zjawiska, które można umieścić w ramach Marca 1968. Marzec 1968 toczył się na kilku planach jednocześnie: łączył w sobie między innymi protest studencki i walkę wewnątrz PZPR. ${ }^{26}$

Zagrożenie w postaci syjonizmu, w ruchu komunistycznym traktowanym jako jednej z herezji, należy umieścić w formule wroga obiektywnego. Syjonizm był wygodną figurą retoryczną, pod którą można było ukryć prymitywny antysemityzm. Żydów można było oskarżyć o różnorodne nadużycia, wykorzystać stereotyp o „żydokomunie”. Kampanię antysemicką prowadzono równolegle $\mathrm{z}$ kampanią antyinteligencką, której częścią była walka z rewizjonistami i kosmopolitami, wrogiem ulokowanym wewnątrz partii. Zaatakowani w 1968 r. twórcy, uczeni, publicyści czy działacze polityczni i społeczni byli polskimi Żydami. Pierwowzór wroga marcowego został stworzony w Związku Radzieckim.

Za początek akcji antysemickiej można uznać zorganizowanie przez MSW i Mieczysława Moczara 17 czerwca 1967 r. demonstracji - ,pożegnania” na Okęciu ambasadora Izraela w Polsce po zerwaniu przez rząd PRL stosunków dyplomatycznych, traktowanego przez media jako ,spontaniczna reakcja ludu Warszawy"27. Natomiast nastroje antyżydowskie sprowokował 19 czerwca 1967 r. Władysław Gomułka przemówieniem w czasie VI Kongresu Związków Zawodowych, w którym - odnosząc się do reakcji środowisk żydowskich wobec konfliktu izraelsko-arabskiego - użył określenia: „,nie chcemy piątej kolumny w Polsce”28. Był to niewątpliwie atak na środowisko żydowskie, który spowodował ożywienie nastrojów antysemickich, na ogół bagatelizowanych przez kierownictwo PZPR.

W 1968 r. komunistyczne władze wykorzystały kryzys do realizacji własnych celów. Kryzys władzy powodował potrzebę szukania nowych instrumentów rządzenia ${ }^{29}$. Zaprogramowana i kontrolowana przez komunistyczne władze sytuacja kryzysowa była elementem strategii, swoistą próbą ,ucieczki do przodu”, w sytuacji gdy społeczne nadzieje związane z powrotem Gomułki do władzy nie spełniły się, a wyczerpał się arsenał środków ideologicznych i politycznych potrzebnych do rządzenia. Przyczyny stworzenia sytuacji kryzysowej przez odwołanie się do kategorii wroga były złożone. $\mathrm{Z}$ perspektywy interesów centrum pozwoliły na realizację co najmniej dwóch celów: 1) na skierowanie niezadowolenia społecznego przez danie ujścia frustracji w antysemityzmie; 2) na dokonanie rotacji u steru władzy. Stwierdzić trzeba, że „odżydzanie” MSW postępowało od 1964 r., a miało związek z powołaniem Mieczysława Moczara na urząd ministra spraw wewnętrznych. Podobne procesy zachodziły w wojsku. Ewidencja

\footnotetext{
${ }^{26}$ A. Friszke, Miejsce Marca 1968 wśród innych „polskich miesięcy”, [w:] Oblicza Marca 1968, red. K. Rokicki, S. Stępień, Warszawa 2004, s. 15.

${ }^{27}$ J. Eisler, Polski rok 1968, Warszawa 2006, s. 106.

${ }^{28} \mathrm{~W}$ tekście przeznaczonym do publikacji wykreślono ów zwrot. Stosowny fragment: D. Stola, Kampania antysyjonistyczna w Polsce 1967-1968, Warszawa 2000, s. 274.

${ }^{29}$ Zob. Biuro Polityczne proponuje. Notatka z dyskusji na posiedzeniu Biura Politycznego z dnia 8 IV 68 r., ,Polityka” 8 VI 1991.
} 
obywateli PRL pochodzenia żydowskiego, jako punkt wyjścia do walki z syjonizmem, postępowała od lata $1967 \mathrm{r}^{30}$.

Antysemityzm był wypróbowanym „,argumentem” uzasadniającym zmiany kadrowe i choć sprzeczny $\mathrm{z}$ internacjonalizmem, był obecny w ruchu komunistycznym. Charakteryzował chociażby politykę personalną Związku Radzieckiego i niektórych innych państw komunistycznych. O „zachwianiu proporcji” między Polakami a Żydami we władzach państwowych i partyjnych wspominał Nikita Chruszczow ${ }^{31}$, któremu zależało na nacjonalistycznej legitymizacji władzy partii komunistycznych, uzyskaniu zaufania społecznego. W połowie lat pięćdziesiątych wrogiem obiektywnym, a zarazem kozłem ofiarnym stali się: Berman, Minc, Zambrowski, wysokiej rangi funkcjonariusze państwowi i partyjni ${ }^{32}$, winni nadużyć w resorcie bezpieczeństwa. Szukano wówczas sposobu na wzmocnienie pozycji kierownictwa. Wyroki skazujące funkcjonariuszy resortu bezpieczeństwa miały pokazać społeczeństwu determinację, wolę i przede wszystkim praworządność sprawujących władzę. Pokazanie winnych, Żydów i funkcjonariuszy Urzędu Bezpieczeństwa miało odwrócić uwagę społeczeństwa od innych współtwórców totalitaryzmu w Polsce. Przykład szedł z Moskwy, gdzie Ławrientij Beria, szef Ludowego Komisariatu Spraw Wewnętrznych (NKWD), był tym stalinowcem, który zainicjował liberalizację systemu i ostatecznie stracił życie.

Należy stwierdzić, że w PZPR dyskutowano na temat składu narodowego gremiów kierowniczych. Antysemityzm był ważnym atutem $\mathrm{w}$ walce $\mathrm{z}$ wrogiem ulokowanym wewnątrz partii. Jako instrument socjotechniczny w wewnętrznej walce o władzę pojawił się w 1956 r. Natolińczycy, jedna z frakcji (Witold Kłosiewicz i Zenon Nowak), wykorzystali żydowskie korzenie współtowarzyszy, aby sprzeciwić się nominacjom na wysokie stanowiska ${ }^{33}$. Z powodów „narodowościowych” blokowano wybór Romana Zambrowskiego do Sekretariatu KC PZPR. Z kolei komuniści z innej frakcji, tzw. puławianie, wykorzystywali sytuację, aby - obwiniając partyjnych przeciwników o

${ }^{30}$ P. Wieczorkiewicz, Walka o władze w kierownictwie PZPR w Marcu 1968, [w:] Marzec 1968. Trzydzieści lat później [materiały konferencji zorganizowanej pod patronatem Prezydenta m. stoł. Warszawy przez Instytut Historyczny UW, Instytut Studiów Politycznych PAN oraz Żydowski Instytut Historyczny przy współpracy Wydawnictwa Naukowego PWN SA na Uniwersytecie Warszawskim 6 i 7 marca 1998 r.], t. 1: Referaty, red. M. Kula, P. Osęka i M. Zaremba, Warszawa 1998, s. 45; K. Lesiakowski, Mieczystaw Moczar „Mietek”. Biografia polityczna, Warszawa 1998, s. 308

31 W jednej z rozmów stwierdził: „Nie jestem antysemitą, ale czego wy chcecie? Naruszenia proporcji? Weźcie, dla przykładu, Polskę. Wiecie, ilu w 1952 r. było Polaków w rządzie? Dwóch. Reszta to Żydzi. Pytałem niejeden raz Bieruta - czym to się skończy? I wiecie, jak się skończyło? W 1956 r. naród powstał właśnie przeciwko tym ludziom. A co było na Węgrzech? Tam też Rákosi [Mátyás] był Żydem, Gerö także. I jak się to skończyło?”, cyt. za: M. F. Rakowski, Dzienniki polityczne 1963-1966, Warszawa 1999, s. 11.

32 A. Paczkowski, Aparat bezpieczeństwa w latach odwilży: casus polski, „Zeszyty Historyczne” 1995/114, s. 3-33.

${ }^{33}$ Zapowiedzią tego, co nastąpiło w marcu, było wystąpienie Zenona Nowaka w czasie VII Plenum KC PZPR w lipcu 1956 roku, podczas którego wymienił polityków pochodzenia żydowskiego piastujących funkcje w ważnych instytucjach. Nowak wspomniał o dokonanej analizie składu personalnego Głównego Zarządu Politycznego WP i Prokuratury Wojskowej; stanowiska były obsadzone przez osoby pochodzenia żydowskiego. Z. Rykowski, W. Władyka, Polska próba. Październik 56, Kraków 1989, s. 210 i n.; A. Friszke, Rozgrywka na szczycie. Biuro Polityczne KC PZPR w październiku 1956, „Więź” 1996/9, s. 188-212. 
antysemityzm - unikać „niewygodnego dla nich problemu odpowiedzialności osobistej za wyczyny $\mathrm{z}$ okresu stalinowskiego"34. Nuty antysemickie pojawiały się zatem w oficjalnym języku rządzących, czego przykładem była wypowiedź Cyrankiewicza o potrzebie kształcenia kadr ,aryjskich"35. Nadreprezentacja Żydów na kierowniczych stanowiskach miała być niewłaściwa. Udział dużej liczby funkcjonariuszy pochodzenia żydowskiego w resorcie bezpieczeństwa był, zdaniem Gomułki, jedną z przyczyn antysemityzmu w Polsce ${ }^{36}$.

W kręgach władzy istniała świadomość niechętnych Żydom nastawień. Odwołanie do antysemityzmu miało przynieść pozytywny efekt. Żydzi najlepiej nadawali się na wroga ze względu na rodzinne powiązania międzynarodowe. Poza tym nie było istotne to, czy Żydzi brali udział w budowie systemu komunistycznego w Polsce, ale to, jakie było na ten temat odczucie społeczeństwa ${ }^{37}$. Działania PZPR jako organizacji masowej odzwierciedlały zjawiska charakterystyczne dla całego społeczeństwa, czyli istniejący de facto antysemityzm i podatność na hasła antyżydowskie ${ }^{38}$.

Kwestia żydowska została zmistyfikowana i sztucznie wykreowana. Nie wiadomo też, jaką rolę w tej kampanii odegrały służby radzieckie ${ }^{39}$. Niewątpliwie władze Związku Radzieckiego były zainteresowane usunięciem wszelakich grup mogących powtórzyć wariant czechosłowacki, czyli doprowadzić do „kontrrewolucji”.

Wystąpienie Gomułki otworzyło nowy rozdział w sytuacji politycznej kraju. „Partyzanci”, frakcja i grupa interesu, której przewodził Mieczysław Moczar, obejmująca partyzantów z AL, skupionych głównie w MSW, młodych aktywistów partyjnych wywodzących się z Związku Młodzieży Polskiej, była zainteresowana awansem. Dążący do eliminacji z aparatu partyjnego, państwowego i ważnych instytucji osób pochodzenia żydowskiego uzyskali dobrą okazję do dyskredytowania niewygodnych dla siebie ludzi i walki o władzę w partii, a co za tym idzie - w państwie.

W warunkach narastającego kryzysu politycznego i gospodarczego władze PRL podjęły wielopłaszczyznowe działania na rzecz umocnienia systemu: 1) poszerzono bazę rządzenia o nowe grupy przez stworzenie swoistego frontu narodowego, wykraczającego daleko poza dotychczasowe zaplecze społeczne, bo skupiającego na przykład środowiska poakowskie czy bezpartyjnych intelektualistów (pozyskaniu kombatantów miało służyć

${ }^{34}$ W. Jedlicki, Chamy i Żydy, „Kultura” 1962/12, s. 3 i n.

${ }^{35}$ AAN, KC PZPR, sygn. 1673, Protokót nr 91 posiedzenia Biura Politycznego KC, 2 maja 1956 r., k. 19-20.

36 A. Garlicki, Wtadystaw Gomutka o marcu 1968, „Przegląd Historyczny” 1993/4, s. 499-518. Gomułka nie miał racji. Badania A. Paczkowskiego dowiodły, że w UB nie było nadreprezentacji Żydów (A. Paczkowski, Żydzi w UB: próba weryfikacji stereotypu, [w:] Komunizm. Ideologia. System. Ludzie..., s. 192-204). Nadreprezentacja dotyczyła kadry kierowniczej resortu. Badania Krzysztofa Szwagrzyka pokazują, że funkcjonariusze pochodzenia żydowskiego mieli 37procentowy udział w kierownictwie resortu Ministerstwa Bezpieczeństwa Publicznego. K. Szwagrzyk, Aparat bezpieczeństwa w latach 1944-1956, [w:] Aparat bezpieczeństwa w Polsce. Kadra kierownicza, t. 1, Warszawa 2005, s. 63.

37 J. Walicki, Bezdroża nauki i publicystyki - o nowej książce Jana T. Grossa, „Dzieje Najnowsze” 2007/1, s. 159.

${ }^{38}$ M. Mazur, Rec.: A. Skalska, Obraz wroga w antysemickich rysunkach prasowych Marca '68, Warszawa 2007, „Dzieje Najnowsze” 2009/2, s. 230; F. Tych, Kilka uwag o Marcu 1968, [w:] Marzec 1968. Trzydzieści lat później..., s. 24-25.

${ }^{39}$ K. Kersten, Polacy - Żydzi - komunizm. Anatomia pótprawd 1939-68, Warszawa 1992, s. 145. 
naprawienie krzywd żołnierzy Armii Krajowej); 2) dokonano zmiany pokoleniowej w elicie władzy; 3) wsparto ideologię elementami typu nacjonalistycznego, niejako „unarodowiono” komunizm, co stwarzało nadzieję na kolejną ofensywę oraz uzyskanie nowej legitymizacji.

Skutkiem kampanii antysemickiej były zmiany kadrowe. Dotknęły pracowników różnych instytucji. Ze stanowiskami pożegnali się obywatele polscy pochodzenia żydowskiego. Opuszczający kraj pozostawili po sobie posady na uczelniach, w aparacie państwowym i partyjnym ${ }^{40}$. Beneficjentami wymuszonej emigracji byli konkretni ludzie, którzy mogli osiągnąć drobne korzyści materialne: objęcie porzuconych stanowisk, kupno od emigrantów mebli, zajęcie zwolnionych lokali mieszkalnych.

\section{WNIOSKI}

Rekapitulując, należy stwierdzić, że system polityczny stworzony przez komunistów potrzebował wroga. Lokalizacja wroga była pochodną przyjętych, wcześniej narzuconych przez suwerena zewnętrznego wskazań ideologicznych, politycznych i wojskowych. Wrogiem kasowym, tak rzeczywistym, jak i obiektywnym i potencjalnym, były różne podmioty: siły społeczne, polityczne i wojskowe związane z poprzednim państwem, a w okresie wojny - Polskim Państwem Podziemnym, państwa kapitalistyczne, a po utrwaleniu władzy kolejne - grupy społeczne, instytucje, środowiska zawodowe, członkowie elity władzy. Kategoria wroga obiektywnego pozwoliła, gdy była taka potrzeba, tworzyć różne jego obrazy. W rzeczywistości Polski Ludowej mniejszości narodowe i ich stowarzyszenia były stałym wrogiem potencjalnym, który w zależności od potrzeb mógł przeobrazić się we wroga obiektywnego i rzeczywistego. W 1968 r. „obcy”, w postaci syjonistów i kosmopolitów, stali się wygodnym kozłem ofiarnym.

\section{LITERATURA}

[1] II Zjazd PZPR, Warszawa 1954.

[2] III Plenum Komitetu Centralnego Polskiej Zjednoczonej Partii Robotniczej (11, 12, 13 listopada 1949 r.), „Nowe Drogi” 1949 [numer specjalny].

[3] V Zjazd Polskiej Zjednoczonej Partii Robotniczej. Stenogram, Warszawa 1969.

[4] VIII Plenum Komitetu Centralnego PZPR 19-21 X 1956 r., ND 1956/10.

[5] Aparat bezpieczeństwa w latach 1944-1956: taktyka, strategia, metody, cz. 2: Lata 1948-1949, oprac. A. Paczkowski, Warszawa 1994.

[6] Aparat bezpieczeństwa $w$ Polsce $w$ latach 1953-1954. Taktyka, strategia, metody, wstęp A. Paczkowski, wybór i oprac. G. Majchrzak, A. Paczkowski, Warszawa 2004.

[7] Aparat bezpieczeństwa w Polsce. Kadra kierownicza, t. 1, Warszawa 200.

[8] Arendt A., Korzenie totalitaryzmu, t. 2, tłum. D. Grinberg, M. Szawiel, Warszawa 2008.

[9] Bäcker R., Totalitaryzm. Geneza. Istota. Upadek, Torun 1992.

[10] Centrum wtadzy. Protokoty posiedzeń kierownictwa PZPR. Wybór z lat 1949-1970, oprac. A. Dudek, A. Kochański, K. Persak, Warszawa 2000.

\footnotetext{
${ }^{40}$ Szczegółowe dane zob. K. Lesiakowski, Emigracja osób pochodzenia żydowskiego z Polski w latach 1968-1969, „Dzieje Najnowsze” 1993/2, s. 117.
} 
[11] Cortois S., Werth N. i in., Czarna księga komunizmu. Zbrodnie, terror, prześladowania, wstęp do polskiego wydania K. Kersten, Warszawa 1999.

[12]Dokumenty do dziejów PRL. Centrum wtadzy. Protokoty posiedzeń kierownictwa PZPR. Wybór z lat 1949-1970, oprac. A. Dudek, A. Kochański, K. Persak, Warszawa 2000.

[13] Eisler J., Polski rok 1968, Warszawa 2006.

[14] Friszke A., Opozycja polityczna w PRL 1945-1980, Londyn 1994.

[15] Friszke A., Rozgrywka na szczycie. Biuro Polityczne KC PZPR w październiku 1956, „Więź” 1996/9.

[16] Garlicki A., Wtadysław Gomutka o marcu 1968, „Przegląd Historyczny” 1993/4.

[17] Garlicki A., Z tajnych archiwów, Warszawa 1993.

[18] Gomułka W., Przemówienie w czasie VIII Plenum KC PZPR, „Nowe Drogi” 1956/10.

[19] Jedlicki W., Chamy $i$ Żydy, „Kultura” 1962/12.

[20] Kersten K., Polacy - Żydzi - komunizm. Anatomia pótprawd 1939-68, Warszawa 1992.

[21] Lesiakowski K., Emigracja osób pochodzenia żydowskiego z Polski w latach 1968-1969, „Dzieje Najnowsze” 1993/2.

[22]Lesiakowski K., Mieczystaw Moczar „Mietek”. Biografia polityczna, Warszawa 1998.

[23] Marzec 1968. Trzydzieści lat później [materiały konferencji zorganizowanej pod patronatem Prezydenta m. stoł. Warszawy przez Instytut Historyczny UW, Instytut Studiów Politycznych PAN oraz Żydowski Instytut Historyczny przy współpracy Wydawnictwa Naukowego PWN SA na Uniwersytecie Warszawskim 6 i 7 marca 1998 r.], t. 1: Referaty, red. M. Kula, P. Osęka i M. Zaremba, Warszawa 1998.

[24]Mazur M., Rec.: A. Skalska, Obraz wroga $w$ antysemickich rysunkach prasowych Marca '68, Warszawa 2007, „Dzieje Najnowsze” 2009/2.

[25] Mironowicz E., Polityka narodowościowa PRL, Białystok 2000.

[26] Oblicza Marca 1968, red. K. Rokicki, S. Stępień, Warszawa 2004.

[27] Olejnik L., Polityka narodowościowa Polski w latach 1944-1960, Łódź 2003.

[28]Paczkowski A., Aparat bezpieczeństwa w latach odwilizy: casus polski, „Zeszyty Historyczne” 1995/114.

[29] Paczoska A., Oskarżeni o separatyzm. Dziatania tajnych stużb PRL wobec działaczy Kaszubskich $w$ latach 1945-1970, „Pamięć i Sprawiedliwość. Biuletyn Głównej Komisji Badania Zbrodni przeciwko Narodowi Polskiemu” 2004/2.

[30],„Polityka” 1991.

[31] Polska Partia Robotnicza. Dokumenty programowe 1942-1948, wyboru i oprac. dokumentów dokonał zespół M. Malinowski i in., Warszawa 1984.

[32] PPR. Rezolucje, odezwy, instrukcje i okólniki Komitetu Centralnego I 1946-I 1947, oprac. W. Góra, B. Halaba, N. Kołomejczyk, Warszawa 1961.

[33] Przemówienie W. Gomułki w czasie XII Plenum KC PZPR [8-9 lipca 1968 r.], ND 1968/8.

[34] Publicystyka konspiracyjna PPR 1942-1945, t. 2, Warszawa 1964.

[35] Rakowski M. F., Dzienniki polityczne 1963-1966, Warszawa 1999. 
[36] Ryszka F., Państwo stanu wyjątkowego. Rzecz o systemie państwa i prawa Trzeciej Rzeszy, Wrocław-Warszawa-Kraków-Gdańsk-Łódź 1985.

[37] Sprawozdanie KC oraz zadania partii $w$ dziedzinie umacniania socjalizmu $i$ dalszego rozwoju PRL [referat I sekretarza KC PZPR tow. Władysława Gomułki], ND 1968/12.

[38] Stobiecki R., Bolszewizm a historia. Próba rekonstrukcji bolszewickiej filozofii dziejów, Łódź 1998.

[39] Stola D., Kampania antysyjonistyczna w Polsce 1967-1968, Warszawa 2000.

[40],,Trybuna Ludu” - 1956.

[41] Walicki A., Marksizm i skok do królestwa wolności: Dzieje komunistycznej utopii, Warszawa 1996.

[42] Walicki J., Bezdroża nauki i publicystyki - o nowej książce Jana T. Grossa, „Dzieje Najnowsze” 2007/1.

\section{FROM CLASS ENEMY TO ETHNIC ENEMY - THE EVOLUTION OF COMMUNIST POLITICAL THOUGHT AS THE EXAMPLES OF THE POLISH WORKERS' PARTY AND THE POLISH UNITED WORKERS' PARTY IN THE YEARS 1942-1968}

The object of discussion were the Polish Workers' Party and the Polish United Workers' Party, Communist parties of Marxist-Leninist ideology, which built a political system of the Peoples' Poland and held political power. The subject of research was a political thought and especially one of its category - the enemy. The aim of the article was to show the evolution of the political thought of the Communist parties using the subject category and taking into account the real enemy and the so-called objective and potential enemy. The political system created by the Communists needed the enemy. The location of the enemy was a derivative of the ideological, political and military indications, accepted and rejected by an external sovereign. Class enemy (so real and objective and potential) were different entities: social, political and military forces associated with the previous state and during the war - Polish Underground State, capitalist states, and after consolidation of power - another social groups, institutions, professional environments, members of the power elite. Potential enemy were minorities and their associations, which, depending on the needs might change into an objective and real enemy. Polish Workers' Party and the Polish United Workers' Party, like other communist parties, used flexible forms and measures to fight with the enemy, depending on the needs: physical violence, discreditation, infiltration, material discrimination. It was characteristic of the period of the struggle for power and its consolidation. Other forms of struggle with enemies were: forced emigration, refusals to issue a passport, 48-hour detention, revisions, blocking possibility of promotion, blocking access to college.

Keywords: political thought, class enemy, ethnic enemy, real enemy, objective enemy, potential enemy

DOI:10.7862/rz.2015.hss.42

Przesłano do redakcji: wrzesień 2015

Przyjęto do druku: październik 2015 